\title{
Building Constructive-Communicative Model for Rural Communities in Using Death Ritual as a Manifestation of Social Virtue
}

\author{
Suyoto $^{1 *}$ and Fery Adhy Permana ${ }^{2}$ \\ ${ }^{1}$ Universitas Muhammadiyah Gresik, Gresik, Indonesia \\ ${ }^{2}$ PT. Permana Sidat Indonesia, Indonesia \\ *Corresponding author email: suyoto@umg.ac.id
}

\begin{abstract}
This study aims to elaborate the meaning of the Rukun Kematian as social virtues; identify the process and implications of the institutionalization of Rukun Kematian and their implications for local initiatives in rural development; and to elaborate communicative actions from Rukun Kematian initiators and the institutionalization of Rukun Kematian. This research was conducted in Pajeng Village, Gondang District, Bojonegoro Regency, using a qualitative approach with phenomenological methods. The data collection techniques used in this research are documentation, participatory observation, in-depth interviews, and FGD (Focus Group Discussion). Research conducted in selected villages, namely Pajeng Village, Gondang District, Bojonegoro Regency, shows that: 1) Social virtues are constructed through configuration and interpolation between meanings with personal-transcendental and social-reciprocal dimensions, quality of representation, shared intention (collective intention) to achieve social and economic benefits, and the presence of generative dialogue; 2) The process of institutionalizing the values of social virtue is determined by the type of validity claims discussed in the public sphere. These claims will color the institutional model. The derivation (derivative) of the institutional model will affect various local initiatives and forms of innovation by citizens in contributing to village development; 3) the communicative actions of the initiators of the Rukun Kematian towards residents in building a mutual understanding are not solely based on two-way rationality and communicative competence. This research also produces a "Constructionist-Communicative Analysis Model for Rural Communities" as well as a mathematical formulation to identify a generative self-governance model in rural communities.
\end{abstract}

Keywords: Values of social virtue, personal-transcendental, social-reciprocal, generative dialogue, socio-economic benefits

\section{INTRODUCTION}

Rukun kematian in Pajeng Village is one of the inspirational traces of social innovation. The phenomenon of Pajeng Village presents an "anomalous face" compared to other villages in the Bojonegoro area. In Islamic religion, which is embraced by the majority of the residents of Pajeng Village, death is a "disaster" for the family left behind. Musibah in Indonesian or disaster in English, comes from the origin of the Arabic word, mushiibatun. The plural form is mashooib, or mushiibat. Literally, musibah (disaster) means something that strike people hardly or something that befalls us. In a general sense, disaster is a test or anything that we don't want. Takziah is a derivation of Islamic virtues based on the hadits which states: man'azzaa mushaaban falahu mitslu ajrihi, or who is comforting people who had a trials from god (bala ') then he gets the same reward as the one who had
suffer"(Narrated by At-Tirmidzi). So in doing takziah, there is a dimension of social obligation to comfort those who experience losing their love ones.

In Bojonegoro villages and Java regions in general, the slametan kematian (praying rituals which is held by family who lost their love ones) is a space to actualize the values of care and solidarity. However, in its progress, these values have now shifted into "obligations" for families affected by disaster. As a result, the death incident has transformed into an "economic disaster" for the family he left behind.

However, what happened in Pajeng Village was very different. The researcher, who has been a district head for two periods in Bojonegoro, feels the need to raise this turning point event as inspiration in developing new approaches related to rural development. Researcher have the intention to explore and elaborate on what the agent of change 
have done to reform the pillars of death so it comes to light what we see today.

In addition, the researcher also intends to identify how the meaning construction process and communicative action plays a role in encouraging the renewal of the death slametan ritual to the Pillars of Death in Pajeng Village. Until now, six Pillars of Death have been formed, each of them has its own institutional and governance "uniqueness".

\subsection{Understanding death ritual}

The ritual of death is a reality that does not appear by itself. In the Social Construction theory put forward by Berger and Luckmann, there is an understanding that reality is socially constructed, where reality and knowledge are two key terms to understand it. Reality is a quality that is contained in phenomena which are recognized as having existence (being) so that it does not depend on human will. Meanwhile, knowledge is the certainty that phenomena are real and have specific characteristics [1]. A reality is described in the social process through actions and interactions, in this case the individual creates continuously a reality that is shared and experienced subjectively [2].

This study identified the global meaning of the death ritual in Pajeng Village with personaltranscendental and social-reciprocal dimensions, as well as reinterpretation of the meaning of the pillars of death of the three groups of sources in this study. Category into these three groups based on biographies, reserves of knowledge and views of sources on the practice of ritual death.

The three groups are: First, the Elders Group with a background as village officials, former village officials, hamlet heads and teachers. They are the holders of authority because of their formal position or historical social legitimacy. Second, the Fundamental Islamic Group, which consists of Qur'an teachers, mosque takmirs, religious teachers and those who are considered to have religious authority. Third, the Kejawen Group, namely the elders and those who are established because of their adherence to local traditions that have long been rooted in Pajeng Village.

The theory of Peter L. Berger and Thomas Luckmann[3] is rooted in the constructivist paradigm which sees social reality as a social construction created by individuals who are free humans. The individual becomes the determinant in the social world which is constructed based on his will. Humans in many ways have the freedom to act outside the limits of control of their social structures and institutions, where individuals go through responses to stimuli in their cognitive world. Every human being constructs a social reality where subjective processes become objectivated in social life.

In the context of the ritual of death in Pajeng Village, the personal-transcendental and socialreciprocal dimensions as "expressed" in an objective meaning, are also not exactly in line with the subjective meaning of the sources in this study. This is reflected in the emergence of three subjective interpretations related to the practice of death rituals in Pajeng Village.

The elders group, views death ritual as an activity that "impoverishes" the people of Pajeng Village. This is because the expenses to pay for the death ritual procession are increasingly burdening the families and their heirs who died. The Fundamental Islamic group, views the ritual of death in certain ways, in fact it is not in line with the teachings of Islam. Meanwhile, the Kejawen group has the view that death rituals is the virtues of the ancestors about how devotion and love someone against people who have passed away. All costs incurred are a consequence of love, respect and loyalty to people who have entered the tinned realm.

In the perspective of social construction, this double interpretation is a necessity. This is because all humans have meaning and try to live in a meaningful world. These various meanings can occur because of the biographical background, reserves of knowledge and reflection on the realities in the social world.

\subsection{Values of death}

The purpose of this study was to elaborate the values of social virtues contained in the death ritual of Pajeng Village. The value of social virtue is a reflection of hopes, ideals, and necessities so that these values have an ideal character (das sollen). Social virtue contains elements of integrity, fairness, temperance, purity, decency, merit, distinction, and excellence [4].

With these elements, an ideal life will be achieved that leads people to be wise, brave, introspective and just. This is in line with Plato[5]'s thought that the highest good in this life is to harmonize the ideal with reality, namely realizing justice, courage, kindness and wisdom through the logical thinking. The highest happiness lies in a life that leads to the highest good and contemplating on the highest ideas such as the values of solidarity, togetherness and justice. In addition to achieving an ideal life, social virtue can also indicate the emergence of a "moral movement" to respond to the decline in collective values [6]. With these social 
virtues, degradation and "deficits of meaning" can be cured[7].

This condition also occurred in Pajeng Village in early 1990. At that time, several people gasped sadly when the one of their resident has passed away "so called" Mrs. Rusmini. The sadness occurred when he saw that there were only a few people attending the pilgrimage. In addition, Mrs. Rusmini, who during her life was full of burden because of her poverty, now has to transfer her burden to the family she left behind. That burden is in the form of "social obligation" to fulfill a series of death rituals, which of course require a lot of funds and resources. Those who gasped it, in the end questioned and reinterpreting the established and entrenched death rituals in Pajeng Village. Through various conversations, they came to the conclusion that "this ritual is an activity of impoverishing and unproductive, the poor will get poorer."

Based on this fact, they initiated the formation of the Pillars of Death. Two objectives of the formation of this pillars of death, first, renew the practice (redesign) of death rituals to ensure that the poor do not get poorer; second, ensuring pillars of death has benefits (utility) for the common interest. From the formulation of the objectives of pillars of death, the spirit of benefit emanates explicitly. A spirit that is based on the principle of seeking the greatest possible benefit or effect for as many people as possible in its actions. Also the principle of justice, so that people do not sacrifice the rights of others in pursuit of the maximum benefit. The intended benefits are not only limited to the actor himself, but for all who can be affected by the act, either directly or indirectly[8].
The benefit and justice principles continues to be socialized by the initiators of pillars of death from the time the pillars of death was founded until now. The benefit model offered by pillars of death initiators is not the same as the utilitarianism model in the flow of moral philosophy which emphasizes preference satisfaction which presupposes an element of rationality involvement in fulfilling utility. However, utilitarianism spirit of "Ngregani, mbantu lan peduli ing liyan" (respect, help and care for others) became the uniqueness of the principles of harmony, harmony and harmony in Javanese ethics. Based on caring for others spirit, the process of institutionalizing pillars of death's social virtues is not instant and equal. By the spirit of "social benefit" which is manifested in respect, help and care for others, it became a discursive process that took place in public spaces in Pajeng Village. Here, the crossing point of Berger and Habermas's[9] approach became the research focus.

\subsection{Communicative Actions from the Pillar of Death's Iniciators}

By using this communicative action perspective, this study has also identified a link between the internalization of experiences, views and references that characteristize the human action, also behavior orientation and choice of social media. This relationship can be seen in the following table :

TABLE 1. The Linkage of Internalization with the Components of Communicative Action

\begin{tabular}{|l|l|l|l|}
\hline & \multicolumn{1}{|c|}{ The elders group } & \multicolumn{1}{c|}{ Islamic fundamental group } & \multicolumn{1}{|c|}{ Kejawen groups } \\
\hline $\begin{array}{l}\text { Background of the } \\
\text { action }\end{array}$ & $\begin{array}{l}\text { Experience and responsibility } \\
\text { answer as protector }\end{array}$ & Upholding of religious values & $\begin{array}{l}\text { Recognition of local } \\
\text { wisdom }\end{array}$ \\
\hline $\begin{array}{l}\text { The nature of the } \\
\text { action }\end{array}$ & Strategic-instrumental action & Strategic Action - Instrumental & Communicative Action \\
\hline $\begin{array}{l}\text { The offender } \\
\text { orientation }\end{array}$ & Influencing others to achieve goals & Influencing others to achieve goals & $\begin{array}{l}\text { Seek understanding } \\
\text { (mutual understanding) }\end{array}$ \\
\hline $\begin{array}{l}\text { Media } \\
\text { used }\end{array}$ & $\begin{array}{l}\text { Through institutions and meetings } \\
\text { formal meeting }\end{array}$ & $\begin{array}{l}\text { Through institutions and forums } \\
\text { religion }\end{array}$ & $\begin{array}{l}\text { Through the spaces } \\
\text { informal dialogue }\end{array}$ \\
\hline $\begin{array}{l}\text { Competence } \\
\text { communicative }\end{array}$ & $\begin{array}{l}\text { First and second stage } \\
\text { competencies }\end{array}$ & First and second stage competencies & $\begin{array}{l}\text { First and second stage } \\
\text { competencies }\end{array}$ \\
\hline
\end{tabular}

Communicative action is an act of communication that directs itself to consensus. The parties can reach consensus in communicating when he is able to understand the intentions and interests of the interlocutor, also convey his intentions and interests, then determine possible arguments to be accepted by both parties. In this communication, the public must make the interlocutor understand the point by trying to reach validity claims. This claim 
is considered rational and will be accepted without coercion as a result of consensus[10].

To reach a consensus, Habermas[11] requires the fulfillment of four valid claims, which include:

- Truth claims: when they can agree on the natural and subjective world,

- Rightness claims: when they agree on the implementation of norms in the world social;

- Claims of sincerity or honesty (sincerety): when they are agree on the congruence between the inner world and one's expression.

- The claim of comprehensibility. Every effective communication must fulfill all four claims. Habermas called people who were able to fulfill these claims as having communicative competence.

The consensus process between groups in forming Pillars of Death took almost 20 years. In this time span, three consensus formation models were found: first, the hegemonic approach model depicted in the Pillars of Death groups I, II and III. Second, the voluntary approach model described in the Pillars of Death group IV, and the third model of the pro-existence approach as depicted in the Pillars of Death groups V and VI. The dynamics of the formation of the six Pillars of Death show that the social construction process of the Rukun Kematian is not an autonomous process as stated by Berger, Habermans [12], view that consensus can only be realized when there is two-way rationality and communicative competence.

\section{METHOD}

This study uses a qualitative approach with the following reasons: first, what is examined is the meaning of an action or what is behind a person's actions. Second, individuals have appropriate action strategies for themselves in dealing with the social environment, so that it requires in-depth study. Qualitative research provides an opportunity to carry out an in-depth study of a phenomenon[13].

\subsection{Field Research Stages}

- Entering Research Field: Preliminary Research. As with qualitative research in general, the position of the researcher is as a objective person who is learning about the phenomenon being studied [14].

- Finding Field Data. In order to understand the meaning behind phenomenon being observed, the data collecting methods used in this research are participatory observation, in-depth interviews, documentation and FGD (Focus Group Discussion)[15].

\subsection{Research Location}

This research was conducted in Pajeng Village, Gondang District, Bojonegoro Regency. This location was decided to be the location of the research because in this village the Rukun Kematian was formed and to date it has developed into six groups. On the other hand, in this village there are still traditional practices and traditional rituals of salvation for death.

\section{RESULT REPORTING}

Analysis procedures and carried out both in data collection and after data collection is complete. Researchers write reports using three procedures, namely: data reduction, data display and conclusion drawing. Data reduction is related to the research objectives, presenting data using narration, while conclusions are made after the data has been collected can be tentative which is always verified during the research [16]

\section{FINDINGS}

With the formulation of the main problems: (a) How is the construction of the meaning of ritual death as a form of social virtue? (b) How is the process of institutionalizing the social virtues of Rukun Kematian and its implications against local village development initiatives; (c) What are the communicative actions of the initiators of the Pillars of Death towards the community? Through these three problems, the researcher intends to find a new spirit and approach that is more contextual and innovative and is able to place the dignity of the community as a subject capable of being an energy for change. This intention based on reality, rural development policies it tends to destroy the social energy and undermine the dignity of the rural community. This is reflected in the emergence of various top-down policies. And, systematically it has become an instrument that leads to the colonialization of public spaces in rural areas. This condition will sooner or later have negative consequences for the future development of rural communities in Indonesia [17].

The phenomenon of Pajeng Village has inspired and given new hope in that situation. From this research, identified opportunities to create reforms that are more dignified, meaningful and have a future dimension [18]. Several points for realizing this renewal can refer to the following conclusions: 
- The values of social virtues are constructed through configuration and interpolation between meanings with personaltranscendental and social-reciprocal dimensions, quality of representation, collective intention to achieve social and economic benefits, and the presence of generative dialogue. The value of social virtue is the result of meeting, bonding, and binding of personal-transcendental meanings such as adherence to religious teachings, personal beliefs, and love and respect for kindship, and social-reciprocal such as friendship and mutual cooperation, which in sociological terms is called the sentiment of locality[19].

- The process of institutionalizing social virtue values is determined by the type of validity claims discussed in the public sphere [20]. These claims will color the institutional model. The derivation (derivative) of the institutional model will affect various types of local initiatives and forms of innovation by citizens in contributing to village development.

- The communicative actions of the initiators of the Pillars of Death towards citizens in building a mutual understanding are not solely based on two-way rationality and communicative competence [21]. Things that significantly influence to achieve a common understanding are the occurrence of generative dialogue, a discursive process of social virtue values, and the existence of a common intention to achieve socioeconomic benefits.

\section{CONCLUSION}

\subsection{Contribution Strategical Values and} Rural Development from Pillars of Death

Strategic suggestions for development and empowerment of rural communities need to be studied, identified and enriched using a communicative-constructionist analysis model, explain as follows:

- For the Government

a) Caring for, accelerating and developing generative dialogues that have lived in rural public spaces, while still based on social virtues, and strive to improve the quality of representation in order to build a common intention towards empowering and dignified rural communities.

b) For the government to build generative self-government in rural areas, it can first be done by directing all elements of the village to focus on the problems at hand. These problems became the development targets of the village government.

c) The government guides with certainty procedures on how to prepare a budget with a partnership scheme, which focuses on solving the problems at hand.

d) Encouraging qualified representation, which does not only rely on technocratic politics, but expands the involvement of those who have been vulnerable, marginalized and not taken into account (silent majority). for example, by involving them in informal and formal public spaces such as village trustees, so that they can care for, give birth to and develop generative dialogue practices in the village.

e) Encourage village governments to generate socio-economic benefits by providing village government performance reports that can be accessed by all residents.

f) Maintain and maintain social virtue in the village and create public trust through transparency, openness and accountability in the village.

Those are 6 things that must be encouraged by the government and of course by training the leadership of the village heads, informal and formal leaders, generative self-government can be realized.

- For rural communities

Maintain and preserve generative selfgovernance practices that have lived in their socio-cultural world. In other words, they cannot withdraw theirself because of they feel inferior to the existing local traditions, because if these traditions are managed properly, they will become discourse spaces that allow them to multiply social capital.

- For Academics, Experts and Observers Rural development is not confined to ideology and scientific concepts, but humbly learns and understand the "universe of meanings" of rural communities, and 
collaborate with each other to accelerate generative self-governance for building constructive rural development model that is more spirited, meaningful and dignified.

\section{REFERENCES}

[1] E. E.-H. \& A. E. (Editor), Social Change: Sources, Patterns, and Sequences. New York: Basic Books, 1974.

[2] C. Geertz, Local Knowledge; Further Essays In Interpretive Anthropology. London: Fontana Press, 1983.

[3] \& L. Berger Peter, L., Tafsir Sosial Atas Kenyataan: Risalah tentang Sosiologi Pengetahuan. LP3ES. Jakata.

[4] R. T. Schaefer, Sociology: A Brief Introduction. New York: McGraw-Hill.

[5] P. B. H. \& C. L. Hunt, Sosiologi. Erlangga. Jakarta.

[6] F. Fukuyama, No TitleKebajikan Sosial dan Penciptaan Kemakmuran terjemahan dari Trust the Social Virtues and The Creation of Prosperity oleh Francis. Penerbit Qalam. Yogjakarta, 2002.

[7] G. Ritzer, Sociological Theory. New York: McGraw-Hill., 2012.

[8] O. Lewis, Kebudayaan Kemiskinan; $d$ Dalam Kemiskinan di Perkotaan. Jakarta: Yayasan Obor, 2010.

[9] K. Schilbrack, "The social construction of 'religion' and its limits: A critical reading of Timothy Fitzgerald," Method Theory Study Relig., vol. 24, no. 2, pp. 97-117, 2012, doi: 10.1163/157006812X634872.

[10] F. F. Rogers, Everett M., Shoemaker, Communication of Innovations. he Free Press: A Division of Mc Millan Publishing Co., Inc., New York.

[11] J. Habermas, On the Pragmatics of Communication. MIT Press, 2000.

[12] \& L. Berger Peter, L., Tafsir Sosial Atas Kenyataan: Risalah tentang Sosiologi Pengetahuan. Jakarta: LP3ES, 2012.

[13] Sugiono, Memahami Penelitian Kualitatif: Dilengkapi Contoh Proposal dan Laporan Penelitian. Bandung: Alfabeta.

[14] Irwanto, Focus Group Discussion. Pusat Kajian Pembangunan Masyarakat. Jakarta: Universitas Katolik Atma Jaya, 2010.

[15] C. Willig, Introducing Qualitative Research In Psychology. New York: Open University Press, 2008.

[16] S. A. \& C. Juliet, Dasar-Dasar Penelitian
Kualitatif: Tatalangkah dan Tehnik-Tehnik Teoritisasi Data. Yogyakarta: Pustaka Pelajar, 2010.

[17] N. Martono, Sosiologi Perubahan Sosial: Perspektif Klasik, Modern, Posmodern, dan Poskolonial. Jakarta: Rajawali Pers.

[18] Nasikun, Sistem Sosial Indonesia. Jakarta: CV Rajawali, 2008.

[19] R. Brislin., Understanding Culture's Influence On Behavior. New York: Harcourt Brace College Publishers, 2008.

[20] G. B. Pierre, J., \& Peters, Governance, Politics and The State. New York: St Martin Press, 2010.

[21] K. Scharmer, C. O., \& Kauefer, Emerging Future: From Ego-System to Eco-System Economies. New York: McGraw-Hill., 2013. 